\title{
Physical Activity and Blood Sugar Levels in People with Diabetes Mellitus: Evidence from Indonesia
}

\author{
M. Arifki Zainaro ${ }^{1 *}$, Ridwan ${ }^{2}$, Rias Tusianah ${ }^{3}$, Sudjarwo ${ }^{4}$, Usastiawaty C. A. S. Isnainy ${ }^{5}$, \\ Albet Maydiantoro ${ }^{6}$, Tubagus Ali Rachman Puja Kesuma ${ }^{7}$, Hasan Hariri ${ }^{8}$, Aprina ${ }^{9}$ \\ ${ }^{1,5}$ Department of Nursing Management, Universitas Malahayati, Bandar Lampung City, Indonesia \\ ${ }^{2}$ SMP Negeri 3 Way Pengubuan, Central Lampung Regency, Indonesia \\ ${ }^{3}$ SMP Negeri 1 Simpang Agung, Central Lampung Regency, Indonesia \\ ${ }^{4}$ Educational Doctor Programme, Universitas Lampung, Bandar Lampung City, Indonesia \\ ${ }^{6}$ Department of Economic Education, Universitas Lampung, Bandar Lampung City, Indonesia \\ ${ }^{7}$ Department of Social Science, Institut Agama Islam Negeri Metro, Metro City, Indonesia \\ ${ }^{8}$ Educational Doctor Programme, Universitas Lampung, Bandar Lampung City, Indonesia \\ ${ }^{9}$ Politeknik Kesehatan Kementerian Kesehatan, Tanjung Karang, Bandar Lampung City, Indonesia \\ *Corresponding Authors
}

Received: June 9, 2021. Revised: December 2, 2021. Accepted: January 5, 2022. Published: January 7, 2022.

\begin{abstract}
Diabetes mellitus (DM) is a slowly deadly disease. Indonesia has the 4th highest number of diabetes mellitus after China, India and the United States. People with diabetes have grown from 8.4 million in 2000 and will become 21.3 million in 2030 . This study aims to determine the relationship between body movement and blood sugar levels in patients with type 2 diabetes mellitus. This type of research is quantitative, with a design analytical research and cross-sectional approach. The sample of this study was 131 people with the criteria for suffering from type 2 diabetes mellitus. Data collection used the Global Body Movement Questionnaire (GPAQ) questionnaire, and the statistical test used was the Chi-Square statistical test. The results showed that there was a relationship between physical activity and blood sugar levels in patients with type 2 diabetes mellitus, so it is recommended that DM patients should routinely carry out body movements and control blood sugar levels in health care facilities and take advantage of health services such as health workers if they experience problems in performing body movements and follow a diabetic diet according to the advice of a nutritionist. In-depth conclusions and implications are discussed.
\end{abstract}

Keywords-Blood Sugar, Activity Physical, Diabetes Mellitus

\section{INTRODUCTION}

$\mathrm{D}$ iabetes mellitus is one of the silent killers as well as is a disease that will trigger the biggest health crisis in the 21 st century. Indonesia is a country with the 4 th highest sum of diabetes mellitus sufferers after China, India, and the United States. Estimates for Indonesia based on WHO predictions say that persons with diabetes mellitus have grown from 8.4 million in 2000 to 21.3 million in 2030, while the International Diabetes Federation (IDF) forecast growth in the sum of people with diabetes in Indonesia from 9.1 million in 2014 to 14.1 million in 2035 [1, 2].

The International Diabetes Federation (IDF) notes that the widespread of diabetes in the globe is 415 million and is forecasted to grow to 642 by 2040 . Meanwhile, the prevalence of diabetes mellitus has increased in Indonesia. In 2013 the widespread of diabetes mellitus in Indonesia was $6.9 \%$, then increased to $8.5 \%$ in 2018 [1].

At the same time, the Lampung Provincial Health Office has noted that in 2017 the number of diabetes mellitus sufferers increased by $12 \%$ from the previous period, which was 38,923 cases.[1] Whereas in Central Lampung District in 2018 cases of diabetes mellitus ranked first in Lampung Province, cases of diabetes mellitus in 2017 were $29.9 \%$, in 2018 it was $32.6 \%$ and increased in 2019 to $34.9 \%$.

There are three kinds of diabetic diseases; type 1, type 2, and gestational. This research mainly focuses on diabetic type 2. Hazard factors for type 2 diabetes mellitus can be divided into modifiable factors and non-modifiable factors. Some of 
the indications of type 2 diabetes that can be recognized early on at least include (1) Repeated urination: when levels of blood sugar are up, our kidneys will dilute surplus sugar by screening it out of the blood [3]. Increased thirst Urinating is needed to get rid of surplus sugar in the blood. However, frequent urination may cause the body to lose additional water. If this condition occurs frequently, a person will become dehydrated so that they feel thirstier than usual; (2) Always feels hungry; human digestive system works by breaking down food into simple sugars called glucose. Glucose is used by the body as fuel during activities. In diabetics, glucose does not move properly from the blood flow to the body's cells. As a result, people with type 2 diabetes many time feel hungry, even though they have just received food intake [3]. Feeling exhausted Type 2 diabetes may have an effect on a people's power levels, causing the person to often sense exhausted. This excess fatigue occurs due to a lack of sugar that moves from the bloodstream to the body's cells; (3) Blurred sight; surplus blood sugar can damage the small blood vessels in our eyes, which may affect blurred vision. This blurred sight can occur in only one eye or it can be in both eyes and can disappear and arise. If this condition is not treated, the decay to the blood vessels can get more very bad, including the possibility of permanent vision; (4) The patient's wound is not healing; High levels of blood sugar can decay strands and blood vessels, which in turn may interfere with blood cycles. As a result, even a little cut or wound may take weeks or months to heal. In fact, slow wound healing can increase the risk of infection; (5) Tingling or numbness in the hands or feet high levels of blood sugar can affect the blood cycle and decay the body's nerves. In persons with type 2 diabetes, this condition can cause pain, a tingling feeling, or numbness in the hands and feet. This situation is known as neuropathy and can get worse continuously, causing serious complications if left untreated; (6) Black skin patches, these black skin patches can shape in the folds of the neck, armpits, or groin. This condition is known as acanthuses nigricans, which may feel soft and velvety in texture; and (7) Itching and yeast infection surplus sugar in the blood and urine equals feeding for yeast, which may eventually head to taint [4].

Prevention efforts are made by reducing modifiable risks. The principle of preventing type 2 diabetes in people at risk is by changing their diet, lifestyle and carrying out regular physical exercise such as exercise and weight loss. Prevention of diabetes mellitus is divided into four parts, namely: Primordial Prevention. Primordial prevention is efforts to provide conditions in society that allow the disease to not receive support from habits, lifestyle, and other risk factors. These preconditions must be created in partnership. Prevention of primordial disease in diabetes, for example, is to create preconditions so that people feel that the consumption of westernized food is a poor diet, a relaxed lifestyle, or lack of activity and obesity is not good for health [5].

Primary Prevention Primary prevention is an effort aimed at people who are included in the high-risk group, namely those who have not suffered from DM but have the potential to suffer DM, including (a) Old age group ( $>45$ years) (b) Obesity (body weight $(\mathrm{kg})>120 \%$ ideal weight or BMI $>27$ (kglm2), (c) High blood pressure ( > 140i90mmHg), (d) Family history of diabetes, (e) History of pregnancy with birth weight $>4000$ gr. (f) Dyslipidemia (HDL $<35 \mathrm{mg} / \mathrm{dl}$ and/or Diabetes Triglycerides > 250mg/dl), and (g) Have had impaired glucose tolerance or fasting blood glucose disturbed impaired fasting blood sugar [4-6].

Body movement is immediately connected to the speed at which muscle blood sugar recovers. During body movement, muscles use the glucose they store so that the stored glucose is reduced. At that time, to fill this deficiency, the muscles take glucose in the blood so that glucose in the blood lessens which can grow control of blood sugar [7].

The impact of body movement is immediately connected to the growth in muscle glucose restoration rate. During the activity, the muscles use up the glucose kept in the muscles and when glucose is reduced, the muscles fill in the gaps by consuming glucose from the blood. This will cause a decrease in blood glucose, therewith growing blood glucose control. The role of body movement in type 2 diabetes mellitus is to manage levels of blood glucose. The prime difficulty in type 2 diabetes mellitus is a shortage of reaction to insulin so glucose cannot get in the cells. Membrane permeability to glucose grows when muscles movement because muscle contraction has insulin-like properties [8].

For primary prevention, factors that influence the onset of DM and efforts to eliminate these factors must be recognized. Therefore it is very important in this prevention. Since his early age, he has been instilled in the importance of a healthy diet, and healthy types of food to keep the body from getting too fat: and the health risks of smoking.

Secondary Prevention, Secondary prevention is an effort to prevent or inhibit complications with action early detection and provide treatment early in the disease. In the management of DM patients, from the beginning, caution must be made and as much as possible prevent the possibility of chronic complications. The main pillars of DM management include a. counseling, b. food planning, c. physical exercise, d. hypoglycemic drug.

Tarsier Prevention, Tertiary prevention is an effort to prevent further disability and rehabilitate the patient as early as possible, before the disability persists. Holistic and integrated health services between related disciplines are needed, especially in referral hospitals, for example, experts in fellow science such as experts in cardiovascular disease, medical rehabilitation, nutrition, and others.

Diabetes Mellitus Type 2 (DM type 2) is metabolic chaos portrayed by growth in blood sugar because of declined insulin secretion by pancreatic beta cells and/or disruption in insulin function that occurs in 3 steps, namely decay to pancreatic B cells due to external effect (viruses, chemicals, etc.), decreased glucose receptors in the protective pancreas, or damage to insulin receptors in peripheral tissues. Patients with diabetes mellitus usually complain of typical symptoms such as polyphagia (lots of eating), polydipsia (lots of drinking), polyuria (a lot of urinating/frequent urination at night) increased appetite but weight loss rapidly (5-10 kg in 24 time) week) easily tired, and tingling. The occurrence of Type 2 diabetes is more common in women because women have a bigger possibility of increasing body mass indicators. Based on the outcomes of Basic Health Research in 2008, the commoners of DM in Indonesia developed is by $57 \%$. Increased occurrence of type 2 Diabetes Mellitus is caused by 
factors such as the family history of diabetes mellitus, age, obesity, high blood pressure, dyslipidemia, glucose tolerance; lack of activity, history of diabetes mellitus is in pregnancy. To establish the diagnosis of Type 2 Diabetes Mellitus, which is found typical complaints and symptoms with the results of the blood test $>200 \mathrm{mg} / \mathrm{dl}$ is by fasting blood glucose $>126$ $\mathrm{mg} / \mathrm{dl}$. Management of Diabetes Mellitus can be done by selecting oral hyperglycemic drugs and insulin as well lifestyle modifications such as diet and regular exercise to avoid complications such as diabetic ketoacidosis, non-ketotic hyperosmolar coma, and chemotactic acidosis, coronary heart disease, congestive heart failure, stroke, nephropathy, diabetic retinopathy (blindness), neuropathy, and diabetic ulcers [9].

Research conducted by Nurayati and Adriani suggests that the relation between Body movements and Fasting Levels of blood sugar of Type 2 Diabetes Mellitus Patients at Mulyorejo Health Center, Surabaya. The results showed that $62.9 \%$ of respondents had low body movement and as many as $58.0 \%$ of respondents had high fasting levels of blood sugar. The outcomes showed that there was a relationship between body movement and fasting levels of blood sugar in persons with Diabetes Mellitus type $2(p=0.000)$ [7].

Many studies have examined this topic, however, there is still a gap in research information from areas where the people who inhabit the research area come from various ethnicities. This research site is in Lampung where the population is a miniature of the diversity of Indonesian ethnic groups, totaling 1,340 ethnic groups. This study aims to close the gap in this research information.

\section{METHODS}

The type of study utilized in this research is quantitative, that is, a type of research that tries to find out why these health problems can occur then conducts an analysis of the relationship.

The design study is used analytic with a cross sectional; the populations in this study were 131 people with type 2 diabetes mellitus at Seputih Banyak Health Center, Central Lampung Regency from January to February 2020. Samples taken in this study were all 131 people with type 2 diabetes mellitus.

Analysis of body movement with levels of blood sugar of patients with type 2 diabetes was analyzed using the ChiSquare $(\chi 2)$ statistical tests with a confidence degree of $95 \%$ and alpha $(\alpha) 5 \%$.

In this study, the authors used data set methods in through questionnaires and observation sheets, where the questionnaire was filled in directly by the respondent. The questionnaire sheet to measure body movements variables using the Global Body movements Questionnaire (GPAQ) consists of 16 questions using a Likert scale. The range of scores of low body movements scores MET $<600$ minutes/week and moderate and strenuous body movements $\geq 600-3000$ minutes/week. Meanwhile, to measure the variable levels of blood sugar by providing a measuring tool Finger Prick Blood/Glucometer."

\section{RESULTS}

\section{A. Characteristics of the Participants}

The authors present the demographic data to give a clearer understanding. The demographic data covers gender, age, level of education which is completed by the frequency and the percentage of each demographic data given. Below is the demographic of the participants as follows.

Table 1. Patient Demographic Data

\begin{tabular}{|c|c|c|}
\hline & Frequency & Percentage \\
\hline \multicolumn{3}{|c|}{ Gender } \\
\hline Male & 72 & 54,83 \\
\hline Female & 59 & 45,17 \\
\hline \multicolumn{3}{|c|}{ Age $\mathrm{M}+\mathrm{SD}$} \\
\hline $40-50$ years & 38 & 29,03 \\
\hline $51-60$ years & 14 & 45,17 \\
\hline$>60$ years & 34 & 25,80 \\
\hline \multicolumn{3}{|c|}{ Education } \\
\hline Elementary & 8 & 6,45 \\
\hline Junior High & 72 & 54,83 \\
\hline Senior High & 42 & 32,27 \\
\hline University & 8 & 6,45 \\
\hline Total & 131 & 100,00 \\
\hline
\end{tabular}

Source: research data processing

\section{B. Body movements}

Below is the data of patients' body movements.

Table 2. Body movements in Patients

\begin{tabular}{lcc}
\hline \multicolumn{1}{c}{ Physical Activity } & Frequency & Percentage \\
Low & 59 & 45,16 \\
Moderate & 51 & 38,71 \\
High & 21 & 16,13 \\
Levels of blood sugar & & \\
Abnormal & 59 & 45,16 \\
Normal & 72 & 54,84 \\
\multicolumn{1}{r}{ Total } & 131 & 100,00 \\
\hline
\end{tabular}

Source: research data processing

Table 2 shows that body movements was in the low category 59 respondents $(45.16 \%)$, body movements was 51 respondents $(38.71 \%)$, and body movements was 21 respondents $(16.13 \%)$. A total of 59 respondents $(45.16 \%)$ were in the abnormal category, while 72 respondents (54.84\%) were in the normal category. Analysis of the Relationship between Body movements and Levels of blood sugar in Patients with Type 2 Diabetes Mellitus 
Table 3 Analysis of the Relationship between Body movements and Levels of blood sugar in Patients with Type 2 Diabetes Mellitus

\begin{tabular}{lccccccc}
\hline \multirow{2}{*}{$\begin{array}{c}\text { Physical } \\
\text { Activity }\end{array}$} & \multicolumn{4}{c}{ Levels of blood sugar } & Total & p-value \\
\cline { 2 - 7 } & \multicolumn{2}{c}{ Abnormal } & \multicolumn{2}{c}{ Normal } & & & \\
\cline { 2 - 7 } & $\mathrm{N}$ & $\%$ & $\mathrm{~N}$ & $\%$ & $\mathrm{~N}$ & $\%$ & \\
\hline Low & 47 & 78,6 & 12 & 21,4 & 59 & 100 & \\
\hline Moderate & 10 & 16,7 & 52 & 83,3 & 62 & 100 & 0,003 \\
\hline High & 2 & 20,0 & 8 & 80,0 & 10 & 100 & \\
\hline Total & $\mathbf{5 9}$ & $\mathbf{4 5 , 2}$ & $\mathbf{7 2}$ & $\mathbf{5 4 , 8}$ & $\mathbf{1 3 1}$ & $\mathbf{1 0 0}$ & \\
\hline
\end{tabular}

The statistical test results $\mathrm{p}$-value $=0.003$ is less than the alpha value (0.05) therefore that there is a connection between body movement and levels of blood sugar in type 2 diabetes mellitus.

\section{DISCUSSION}

The authors present the discussion of the result of the research as follows:

\section{A. Levels of blood sugar}

Referring to the outcomes of data collection, we know that levels of blood sugar in diabetes mellitus patients at Seputih Banyak Health Center, Central Lampung Regency in 2020, with an abnormal category of 59 respondents (45.16\%), while the normal category was 72 respondents $(54.84 \%)$.

Glucose intolerance is one of the manifestations of metabolic syndrome which can precede diabetes mellitus. Fasting blood glucose is one way to identify diabetes mellitus in a person. In this disease, sugar is not ready to be transferred into cells, resulting in hyperglycemia as a result that glucose remains in the blood vessels [10].

This research is underpinned by research conducted by [7]. It revealed that the relationship between body movement and fasting of levels of blood sugar of Type 2 Diabetes Mellitus Patients at Puskesmas Mulyorejo Surabaya. The results showed that $58.0 \%$ of respondents had high fasting levels of blood sugar. The outcomes indicated that there was a relationship between body movement and fasting levels of blood sugar in people with Diabetes Mellitus type $2(\mathrm{p}=$ 0.000).

Based on this, the researchers argue that the management of levels of blood sugar is said to be regular if it is done periodically which includes checking fasting sugar levels and levels of blood sugar 2 hours after eating or only regularly checking HbAlc only. The patient's understanding of his condition is very important because the blood glucose level is constantly changing. A patient must have sufficient knowledge about his disease to be able to keep blood sugar within normal limits so as to prevent complications of diabetes. Some things that can help patients to avoid these complications are education, dietary support, a healthy lifestyle, and close monitoring of blood glucose.

There are several things you need to know in controlling blood sugar and diabetes[11], namely: Eat healthily. What you eat can affect levels of blood sugar. Therefore, maintaining food intake is very important for diabetics. It is advisable to eat lots of vegetables, fruit, adequate sources of fiber, fish, and reduce foods high in sugar, processed meat, processed foods, and processed foods that are salty. Don't forget to also eat whole grains and milk or lean meats and avoid sugary drinks, including caffeinated drinks. Also, learn how to calculate the size and portion of carbohydrates. Most importantly, don't forget the drugs from the doctor give to control the blood sugar.

Doing Exercise. Exercise is an important part of managing diabetes as well as an easy, healthy way of life. When exercise, muscles use sugar (glucose) for energy. The body also uses insulin more efficiently. As a result, the blood sugar level will drop. It is advisable to consult with a doctor first to determine what exercise is suitable and for how long. Also, check levels of blood sugar before and after exercise.

Having Routine check-ups. It is advisable to carry out routine health checks at least every six months, including examinations for heart disease, measuring cholesterol and blood pressure levels, as well as other physical examinations such as eyes, teeth, and feet.

Reduce stress. Stress is considered to make levels of blood sugar rise; this is because the hormones produced in the body during stress can prevent insulin from working properly. Avoid stress by increasing the activities you enjoy, such as reading books, traveling, or listening to music, to help reduce stress. In addition, do a variety of relaxation techniques and get enough rest.

Quit smoking. Smoking can expand the risk of various complications of diabetes, like heart illness, eye disease, stroke, kidney, blood vessels, and nerve decay. A person with diabetes who smokes is considered more likely to die from cardiovascular disease than a nonsmoker. Consult with your doctor for advice on the right way to quit smoking.

Also, limit your alcohol intake as it can affect the increase in blood sugar, depending on how much you drink. If you still want to drink alcohol, it is advisable not to drink more than one glass. Calculate alcohol consumption as a carbohydrate intake that should be limited each day. In addition, it is important to check levels of blood sugar before bed.

\section{B. Body movements}

Referring to the outcomes of data collection, we know that body movements in diabetes mellitus patients at Seputih Banyak Health Center in Central Lampung Regency in 2020, with the category of low body movement as many as 59 respondents (45.2\%), moderate body movements as many as 51 respondents $(38.71 \%)$, and high body movements as many as 21 respondents $(16.13 \%)$.

Body movement is all body movements that turn on calories, for example sweeping, going up and downstairs, ironing, gardening, and exercising. Aerobic exercise that follows a series of sequential movements will strengthen and develop muscles and all parts of the body, including walking, swimming, jogging, or gymnastics. For diabetes sufferers, regular exercise will provide more benefits. Blood sugar and fat decrease, blood circulation is better, blood pressure is more stable, and body weight decreases [12].

Body movements and exercise are beneficial for everyone because they can improve fitness, prevent excess weight, improve the function of the heart, lungs, muscles, and slow down the aging process. Thus exercise will also be useful for 
preventing diabetes attacks. The recommended exercise is aerobic. Types of aerobic exercise include brisk walking, cycling, jogging, and swimming, it is recommended to exercise 30-45 minutes a day with a frequency of 4-5 times per week [6].

This is in line with research conducted by Rahayu, et al. [13] regarding factors related to levels of blood sugar in type 2 diabetes mellitus sufferers (Study in the Work Area of the Kedungmundu Public Health Center, Semarang City. It is known that most respondents have leveled of moderate body movements $(71.4 \%)$.

The outcomes of this study also agree with the results of study conducted by [7] the study revealed the relationship between body movement and fasting Levels of blood sugar of Type 2 Diabetes Mellitus Patients at Puskesmas Mulyorejo Surabaya. The results showed that $62.9 \%$ of respondents had low body movements. There is a relationship between body movements and fasting levels of blood sugar in people with Diabetes Mellitus type $2(\mathrm{p}=0.000)$.

Based on this, the researchers argue that body movement can control blood sugar, glucose will be changed into energy during body movement. Body movement causes insulin to grow so that levels of blood sugar will decline. In persons who rarely exercise, food substances that enter the body are not used but are stored in the body as fat and sugar, if insulin is not sufficient to change glucose into energy, DM disease will occur. Body movements also plays a major role in controlling blood sugar in contracting muscles or active requires no less insulin to enter glucose into cells because active muscles are more sensitive to insulin, so levels of blood sugar drop. To control, the patient needs exercises.

The following types of exercise for diabetics are easy to do in your daily routine, such as:

1) Walk briskly. Fast walking can be done by everyone. This exercise is a form of aerobic exercise that is useful for increasing heart rate so that blood flow becomes smoother. This sport is one of the most appropriate activities because diabetics can adjust the intensity according to their physical abilities and health conditions. If your physical condition is strong enough, you can try walking uphill or hiking. Walking uphill for $3 \mathrm{~km} /$ hour can burn 240 calories in one hour. Therefore, this exercise is very suitable to help lose excess weight which can cause diabetes.

2) Diabetes exercise. Gymnastics focuses on adjusting physical movements to the rhythm that is played. This type of exercise is very good for diabetes people. Diabetes exercise can help improve blood circulation in diabetics. Smooth blood circulation can increase metabolism in the body so that it helps insulin absorption. Diabetes exercise is no different from most exercise. Each movement aims to stretch as well as relax muscles and joints. Some diabetes gymnastics movements that can be tried include: Warm up first by stretching your hands so that they are parallel to the shoulders forward and to the sides alternately. Repeat until the body feels warm and ready to move into the core. With your body standing straight, step your feet forward with your left foot still in place. Raise your right hand so that it is parallel to your shoulders and your left hand bends towards your chest. Repeat this movement with the left hand. Do it alternately for several times. Make sure to do the cool down motion when you are done by relaxing your legs together. Bend your left leg forward while keeping your right leg straight. Repeat this movement in reverse on the other leg. Diabetic foot exercise another type of exercise that is recommended for diabetics is foot exercises. Leg exercises can be done while standing, sitting, sleeping, and while relaxing while watching TV. Follow these steps to try diabetic foot exercises: Move your feet by alternately lifting and lowering your heels. Gymnastic movements can also be done by turning the ankles in and out. Straighten your toes until they feel stretched. Lift your leg until it forms a 90 degree angle with your body and then lower it. Do it alternately for both legs. In addition, you can also try diabetes exercise by following the movements in the Tai Chi martial art that originated in China. Unlike aggressive martial arts movements, tai chi moves are slow, smooth, and concentrated. In each session, tai chi exercise is also accompanied by breathing exercises. Therefore, exercise for diabetes can calm the body and mind. This sport is very beneficial for diabetics because it improves fitness and mental health. One of the most important benefits is controlling levels of blood sugar and reducing the risk of nerve damage due to complications of diabetes.

3) Doing Yoga. Yoga combines body movements that build flexibility, strength, and balance. The form of physical exercise in yoga helps people with diabetes reduce stress, improve nerve function, fight insulin resistance, and maintain levels of blood sugar. This is because yoga is one of the sports for diabetes that can increase muscle mass and help to manage stress. Another plus, diabetics can do yoga exercises as often as possible according to their health conditions.

4) Cycling. Cycling is a form of aerobic exercise that strengthens the heart and improves lung function. In addition, this exercise also increases blood flow to the legs and burns calories to maintain the weight of diabetics. To avoid falls and injuries or bad weather, it is better if cycling is done using a stationary bicycle.

5) Weight training. This exercise is recommended for its main benefit of increasing muscle mass. When muscle mass increases, diabetics will find it easier to control blood sugar. Weightlifting can help your body respond better to insulin. As a result, the body can improve the absorption and use of blood sugar optimally. However, to do this sport, diabetes sufferers must get permission from a doctor considering the risk of injury is quite large. 6) Swimming. This exercise is ideal for diabetics because it does not put pressure on the joints. Swimming is easier to do than running because it can reduce excess blood flow to the small blood vessels. On the other hand, swimming actually trains both your upper and lower body muscles at the same time [11].

\section{The relationship between body movements and levels of blood sugar}

The statistical test results $\mathrm{p}$-value $=0.003$ is less than the alpha value (so that there is a relation between body movement and levels of blood sugar in patients with type 2 diabetes mellitus at Seputih Banyak Health Center, Central Lampung Regency in 2020.

Diabetes mellitus complications may happen because of poor levels of blood sugar. To manage the levels of blood sugar under control, it is necessary to treat and manage 
diabetes. Strategies in carrying out diabetes care and management to get comfort levels of blood sugar include doing medical education, medical nutrition therapy, and regular activities. Another thing that is no less significant in managing diabetes mellitus is examining levels of blood sugar periodically [13].

This study is in line with the theory put forward. Physical exercise is one of the pillars in the management of T2DM if it is not accompanied by nephropathy. Daily physical activities and physical exercises are carried out regularly 3-5 times per week for about 30-45 minutes. The break between workouts is not more than 2 consecutive days [14].

This is also in accord with the theory put forward by [12], during exercise, muscles contract and then experience relaxation. Sugar will be utilized and burned for energy, for energy needs, blood sugar will be changed from the blood to the muscles during and after exercise. Thus, blood sugar will drop. In addition, exercise makes insulin more sensitive. Insulin will work better to open the doorway for sugar into cells. As a result, the need for insulin will be lessen. During regular exercise, you will lessen the use of oral anti-diabetes drugs or insulin injections; you can control diabetes only with diet and exercise.

Body movements that are done by a person will affect his levels of blood sugar. Growth of use of glucose by muscles will develop when a person performs the high body movements. This is because endogenous glucose will be increased to keep levels of blood sugar balanced. Under normal circumstances, the balance of levels of blood sugar can be achieved by various mechanisms of the nervous system, glucose regulation, and hormonal conditions. Another theory states that body movements are directly related to the speed at which blood sugar is recovered from muscles. When body movement is done, the muscles in the body will respond by consuming the stored glucose so that the stored glucose is decreased. In this situation, there will be a muscle reaction in which the muscles will take up glucose in the blood so that glucose in the blood decreases and this can develop blood sugar control $[7,15]$.

The effect of body movements is directly by increasing the speed of blood restitution (even the slightest amount that draws blood from the bloodstream). During muscle activity, it uses up the glucose stored in the muscles and if it is depleted, fills in the gaps by consuming glucose from the blood. This will cause in a decline in blood. The role of body movements in type 2 diabetes mellitus is to regulate levels of blood sugar. The prime issue in type 2 diabetes mellitus is shortage of reaction to insulin (insulin resistance) so that glucose cannot get in the cells. The penetrability of the membrane to glucose develops when muscles contract because the muscle contracts insulin-like properties. Therefore, during body movements, insulin decreases [16]. Body movement plays as blood sugar control and weight loss in diabetes mellitus. Body movements is very important in the management of diabetes mellitus, especially as controlling blood sugar and developing cardiovascular hazard factors like reducing hyperinsulinemia, developing insulin responsiveness, cutting body fat, and lowering blood pressure. Routine body movements is integrated with a decrease in mortality by around $45-70 \%$ in the population of type 2 diabetes mellitus and lowering levels of blood sugar which can prevent complications [8].

The outcomes of this research are in accord with the research of [7]. The relation between body movements and fasting Levels of blood sugar of Type 2 Diabetes Mellitus Patients at Puskesmas Mulyorejo Surabaya. The results showed that $62.9 \%$ of respondents had low body movements and $58.0 \%$ of respondents had high fasting levels of blood sugar. The results showed that there was a relationship between body movements and levels of blood sugar in people with Diabetes Mellitus type $2(p=0.000)$.

The outcomes of this study are also underpinned by study done by [8], regarding the relationship between body movements and sleep quality with levels of blood sugar in patients with type 2 diabetes mellitus at the Internal Medicine Polyclinic, dr. M. Haulussy Ambon. The results showed that there was a significant relationship between body movements and levels of blood sugar, $\mathrm{p}=0.002$.

Referring to the results of cross-tabulation, it is shown that 14 respondents with the category of low body movements and normal levels of blood sugar were $21.4 \%$. Meanwhile, 5 respondents with high body movements' category but abnormal levels of blood sugar were 1 respondent $(20 \%)$. This is due to the factor body mass index (BMI) $\geq 25 \mathrm{~kg} / \mathrm{m} 2$, family history of DM, women with a history of giving birth to babies weighing $\geq 4000$ grams or a history of gestational diabetes, hypertension, HDL cholesterol $<35 \mathrm{mg} / \mathrm{dl}$ and or triglycerides $\geq 250 \mathrm{mg} / \mathrm{dl}$, women with polycystic ovary syndrome, history of impaired disorders or impaired fasting blood glucose. Other situation integrated with insulin resistance and a history of cardiovascular illness [17].

This study is in line with study done by Saralangi, et al. [18], that is, there is a relation between body movements (sports) and the occurrence of complications of type 2 diabetes mellitus. Correlation coefficient value Kendal tau is negative $(-0,420)$, which means that the better exercise behavior, the lower the happening of complications of type 2 diabetes mellitus. Other studies that are in line with the above outcomes are a study done by Aplihah and Wulandari [19], which told that there was an effect of foot exercise and marble therapy on peripheral neuropathy. Body movements has a very important role in diabetes management, including lowering the average $\mathrm{A} 1 \mathrm{C}$ value average $0.66 \%$ in type $2 \mathrm{DM}$ patients. Another benefit of body movements is increasing insulin sensitivity $[20,21]$. A decrease in A1C concentration can be utilized as an parameter in reducing the hazard of diabetes complications and death [22]. The benefits of body movements include controlling levels of blood sugar , increasing $\mathrm{HDL}$, lowering LDL, reducing weight body, improve musculoskeletal symptoms (tingling, itching, rheumatic pain at the fingertips) [23, 24]. Body movements can also improve peripheral flow and increase oxygen supply [17]. A person with diabetes must remain active in body movements. Before doing body movements, levels of blood sugar should be a consideration. Incorrectly interpreting body movements and ignorance of anything a person with diabetes should be aware of can be fatal. Regular body movements and according to the rules will reduce the risk of complications of $\mathrm{DM}$, one of which is diabetic peripheral neuropathy [25]. 
According to the opinion of researchers that body movements and exercise are beneficial for everyone because they can improve fitness, prevent excess weight; improve heart function, muscles, and the aging process. Thus, exercise will also be useful for preventing diabetes. The recommended exercise is aerobic. Types of aerobic exercise include brisk walking, cycling, jogging, and swimming which are recommended to exercise 30-45 minutes a day with a frequency of 4-5 times per week $[14,26]$.

\section{CONCLUSION}

This study concluded that Type 2 diabetes mellitus sufferers are more experienced by men aged 51-60 years with junior high school education in this area. The patient's blood sugar levels are not typical. The patient's body movement is low. There is a relationship between body movement and blood sugar levels in patients with type 2 diabetes mellitus.

\section{SUGGESTION}

\section{A. Place of research}

It is hoped that paramedics can play an active role in monitoring the levels of blood sugar of patients with diabetes type 2 and conducting health education related to PROLANIS. PROLANIS is a health service system and a proactive approach that is implemented in an integrated manner involving Participants, Health Facilities and BPJS Health in the context of health care for BPJS (Social Security Administering Agency) Health participants who suffer from chronic diseases to achieve an optimal quality of life. exercise, providing leaflets or posters to patients. And it is hoped that it will be additional information for health service managers to continue the diabetes exercise schedule. In addition, it can be used as input for evaluating activity programs, by doing diabetes exercises at least twice a week.

\section{B. Type 2 DM patients}

It is hoped that DM patients should routinely carry out physical activities and routinely control levels of blood sugar in health care facilities and take advantage of health services such as discussing with health workers if they experience obstacles in carrying out body movements. As well as running a diabetes diet according to the rules recommended by nutritionists.

\section{For further Research}

The authors suggest for further research it is important to conduct research with qualitative research types to complement the results of this quantitative research.

\section{REFERENCES}

[1] R. Kemenkes, "Hasil utama RISKESDAS 2018," Online) http://www.depkes.go.id/resources/download/infoterkini/materi_rakorpop_2018/Hasil\% 20Riskesdas, vol. 202018, 2018.
[2] D. De Zeeuw et al., "Proteinuria, a target for renoprotection in patients with type 2 diabetic nephropathy: lessons from RENAAL," Kidney international, vol. 65, no. 6, pp. 2309-2320, 2004.

[3] N. Permendikbud, "24. Kompetensi Inti dan Kompetensi Dasar Pelajaran pada Kurikulum 2013 pada Pendidikan Dasar dan Pendidikan Menengah," Kompetensi Inti dan Kompetensi Dasar Pelajaran pada Kurikulum 2013 pada Pendidikan Dasar dan Pendidikan Menengah, 2016.

[4] H.-H. Parving, H. Lehnert, J. Bröchner-Mortensen, R. Gomis, S. Andersen, and P. Arner, "The effect of irbesartan on the development of diabetic nephropathy in patients with type 2 diabetes," New England Journal of Medicine, vol. 345, no. 12, pp. 870-878, 2001.

[5] A. Hussain, B. Claussen, A. Ramachandran, and R. Williams, "Prevention of type 2 diabetes: a review," Diabetes research and clinical practice, vol. 76, no. 3, pp. 317-326, 2007.

[6] Soedarsono, "Bebas Diabetes Cara Alami \& Natural," ed: Ecosystem Publishing, 2019.

[7] Nurayati and Adriani, "Hubungan Aktifitas Fisik dengan Kadar Gula Darah Puasa Penderita Diabetes Mellitus Tipe 2," Jurnal Amerta Nutrition. 80-87 80 DOI : 10.2473/amnt.v1i2.2017.80-87, 2017.

[8] D. F. Sumah and T. F. Huwae, "Hubungan Aktivitas Fisik dan Kualitas Tidur Dengan Kadar Gula Darah Sewaktu Pada Pasien Diabetes Melitus Tipe 2 di Poliklinik Penyakit Dalam RSUD dr. M. Haulussy Ambon," Molucca Medica, pp. 1-9, 2019.

[9] A. J. Lee, R. J. Hiscock, P. Wein, S. P. Walker, and M. Permezel, "Gestational diabetes mellitus: clinical predictors and long-term risk of developing type 2 diabetes: a retrospective cohort study using survival analysis," Diabetes care, vol. 30, no. 4, pp. 878-883, 2007.

[10] Sudoyo, A. Setiyohadi, Simadibrata, and Setiati., Buku Ajar Ilmu Penyakit Dalam. Jilid III Edisi VI. Jakarta: Interna Publishing, 2015.

[11] J. P. Crandall et al., "The prevention of type 2 diabetes," Nature clinical practice Endocrinology \& metabolism, vol. 4, no. 7, pp. 382-393, 2008.

[12] H. Tandra, Segala sesuatu yang harus anda ketahui tentang diabetes. Gramedia Pustaka Utama, 2017.

[13] K. B. Rahayu, L. D. Saraswati, and H. Setyawan, "Faktor-Faktor yang Berhubungan dengan Kadar Gula Darah pada Penderita Diabetes Melitus Tipe 2 (Studi di Wilayah Kerja Puskesmas Kedungmundu Kota Semarang," Jurnal Kesehatan Masyarakat (e-Journal), vol. 6, no. 2, pp. 19-28, 2018.

[14] K. A. Cradock, G. ÓLaighin, F. M. Finucane, H. L. Gainforth, L. R. Quinlan, and K. A. M. Ginis, "Behaviour change techniques targeting both diet and physical activity in type 2 diabetes: A systematic review and meta-analysis," International Journal of Behavioral Nutrition and Physical Activity, vol. 14, no. 1, pp. 1-17, 2017.

[15] J. A. Barnes, M. A. Eid, M. A. Creager, and P. P. Goodney, "Epidemiology and risk of amputation in patients with diabetes mellitus and peripheral artery 
disease," Arteriosclerosis, Thrombosis, and Vascular Biology, vol. 40, no. 8, pp. 1808-1817, 2020.

[16] T. G. Arnason, M. W. Bowen, and K. D. Mansell, "Effects of intermittent fasting on health markers in those with type 2 diabetes: A pilot study," World journal of diabetes, vol. 8, no. 4, p. 154, 2017.

[17] C. M. Rendi and T. Margareth, "Asuhan keperawatan medikal bedah dan penyakit dalam," 2012.

[18] R. Saralangi, S. Okti, M. Kep, S. Ns, and A. K. Kartinah, "Hubungan Olahraga Dengan Kejadian Komplikasi Diabetes Mellitus Tipe 2 Di RSUD Dr. Moewardi Surakarta," Universitas Muhammadiyah Surakarta, 2016.

[19] A. Aplihah and I. Wulandari, "Pengaruh Senam Kaki Diabetik Dan Terapi Kelereng Terhadap Neuropati Perifer Pasien Diabetes Melitus Tipe II," Faletehan Health Journal, vol. 4, no. 5, pp. 271-276, 2017.

[20] A. D. Association, "13. Management of diabetes in pregnancy," Diabetes Care, vol. 40, no. Supplement 1, pp. S114-S119, 2017.

[21] D. R. Divaniary, "Hubungan Kadar Kolesterol LDL Dengan Kadar Asam Urat Pada Penderita Diabetes Melitus Tipe 2 Di Klinik Parahita Surabaya Periode 2014-2015," Universitas Airlangga, 2020.

[22] A. W. Sudoyo, B. Setiyohadi, I. Alwi, M. Simadibrata, and S. Setiati, "Buku Ajar Ilmu Penyakit Dalam. Jakarta," ed: Interna publishing, 2009.

[23] A. S. Wahyuningsih, T. Huriah, and N. K. Sari, "Hubungan Kadar Gula Darah dengan Insomnia pada Penderita Diabetes Melitus," The Indonesian Journal Of Health Science, vol. 7, no. 1, 2016.

[24] R. N. Sari, "Diabetes Mellitus (Dilengkapi Dengan senam DM)," 2012.

[25] T. D'Isanto, A. Manna, and G. Altavilla, "Health and physical activity," Sport Science, vol. 10, no. 1, pp. 100105, 2017.

[26] W. Sami, T. Ansari, N. S. Butt, and M. R. Ab Hamid, "Effect of diet on type 2 diabetes mellitus: A review," International journal of health sciences, vol. 11, no. 2, p. 65, 2017.

\section{Creative Commons Attribution License $\mathbf{4 . 0}$ (Attribution 4.0 International, CC BY 4.0)}

This article is published under the terms of the Creative Commons Attribution License 4.0

https://creativecommons.org/licenses/by/4.0/deed.en_US 